\title{
Az ISKOLAI KÖZÖSSÉGI SZOLGÁLAT DIÁKATTITÚDJÉNEK VIZSGÁLATA VÉGZŐS KÖZÉPISKOLÁSOK KÖRÉBEN
}

\author{
BODÓ MÁRTONa - MARKOS VALÉRIA ${ }^{\mathrm{b}, *}$ \\ ${ }^{a}$ Oktatáskutató és Fejlesztő Intézet \\ ${ }^{\mathrm{b}}$ Debreceni Egyetem
}

\begin{abstract}
Kutatásunk 12. és 13. évfolyamos középiskolás diákok közösségi szolgálatra vonatkozó véleményeit elemzi. Az elemzett adatok azt mutatják, hogy a diákok számára az élmények bár örömteliek voltak az IKSZ-ben, annyira nem volt érdekes a tevékenység, hogy azt folytassák. A készségfejlődés kapcsán különbségek mutathatók ki a nem, az iskolatípus és az iskolafenntartó szerint. Az adatok azt mutatják, hogy a lányoknál az állampolgári készségek, a szakgimnazistáknál a pályaorientációs készségek, míg az egyházi fenntartású intézmények tanulóinál az előítélet-mentes és állampolgári készségek fejlődtek.
\end{abstract}

Kulcsszavakः iskolai közösségi szolgálat, attitűd, készségfejlődés

Our research analyzes the views of 12 th and 13th-grade high school students about school community service. The data analyzed shows that for students, the experiences were joyful, but the activity was not so interesting to continue with. There are differences along with skills development by gender, school type, and school maintainer. The data show that among the girls have grown the civic skills, among the vocational school students grown the career orientation skills, and among the students in church-based institutions grown have developed unprejudiced and civic skills.

Keywords‡ school community service, service-learning, attitudes, skills development

\section{Bevezetés}

$\mathrm{H}$ azánkban az iskolai közösségi szolgálat (IKSZ) 2012-es bevezetése óta kevés olyan országos vizsgálat készült, mely a tanulók közösségi szolgálattal kapcsolatos tapasztalatait vizsgálja. Korábban vizsgáltuk a szolgálat gyakorlati megvalósulását, a felkészítő és feldolgozó órák szerepét, a területválasztási aspiráció-

\footnotetext{
* Levelező szerző: Markos Valéria, Debreceni Egyetem, 4032 Debrecen, Egyetem tér 1.

E-mail: markosvaleria.90@gmail.com
} 
kat, a szolgálati célok megvalósulását, és felhívtuk arra is a figyelmet, hogy milyen hiányosságokkal küzd a program (Bodó et al. 2017). Arra azonban nem tértünk ki, hogy a közösségi szolgálattal kapcsolatban milyen attitűdökkel rendelkeznek a fiatalok, illetve milyen készségfejlődésről számoltak be a szolgálat teljesítését követően. Jelen tanulmányunk elsődleges célja ezek vizsgálata.

Korábbi kutatási eredményeink azt mutatták, hogy a középiskola típusa jelentős mértékben befolyásolja a fiatalok közösségi szolgálattal kapcsolatos tapasztalatait és attitüdjeit, hiszen a szakképzésbe járó diákok igyekeznek a saját szakterületüknek megfelelő területet választani (például az egészségügyi szakgimnáziumba járó diák egészségügyi területen végzi a szolgálatot) (Markos 2016). Velkey (2014) kutatásai azt mutatták, hogy a diákok saját bevallásuk szerint toleránsabbak, elfogadóbbak, türelmesebbek lettek, élettapasztalatot szereztek a programban való részvétel által. Karlowits-Jubász (2015) szerint a kötelező iskolai közösségi szolgálat kontextusában is elmondható, hogy a lányok magasabb empátiával és beleélő képességgel rendelkeznek, mint a fiúk. Ezt az eredményt Zsolnai (1998), valamint Zsolnai és Kasik (2006) vizsgálatai általánosságban is alátámasztják, vagyis ebben az életkorban a lányok empatikusabbak, együttműködőbbek és jóindulatúbbak a fiú társaiknál.

A hazai és nemzetközi szakirodalom felhívja a figyelmet arra, hogy a közösségi szolgálat számos készséget (például kommunikáció, együttműködés, empátia, konfliktuskezelés, tolerancia stb.) fejleszt (Markus-Howard-King 1993; Matolcsi 2013). Sigmon (1994) tipológiája szerint azonban nem lehet egységesen megítélni a szolgálati programokat, mert attól függően más és más kimenetele lesz a programnak, hogy mi a célja, elsősorban szolgálat vagy elsősorban tanulás, vagy mindkettő.

Korábbi kutatási eredményeink szerint a készségfejlődés tekintetében a legtöbb diák a kommunikációs készséget, a másokra való odafigyelést és az együttmüködést hangsúlyozta. A gimnazisták fogalomhasználatában gyakrabban jelenik meg a közösségi szolgálat és az önkéntességgel kapcsolatos fogalmak, míg a szakgimnáziumi és szakközépiskolai tanulók elsősorban a munka és kötelező jellegét hangsúlyozzák a tevékenységnek. A lányok sokkal nagyobb százalékban végeznének később önkéntes munkát (59\%), mint a fiúk (41\%). A szakgimnáziumok, szakközépiskolák és a gimnáziumok között éles különbség viszont nem rajzolódott ki (Bodó et al. 2017).

\section{Hipotézisek, adatbázis, módszerek}

Eddigi kutatásaink alapján azt gondoljuk, hogy a nem, a lakóhely, az oktatási intézmény típusa befolyásolja a közösségi szolgálattal kapcsolatos attitüdöket, hiszen számos paraméterét a közösségi szolgálat megvalósításának az iskola dönti el (területek, fogadó intézmények köre stb.). Feltételezzük, hogy bizonyos jellemvonásokra (empátia, együttmüködő készség, jóindulat stb.) a közösségi szolgálat során kiemelt szükség van, a lányok pozitívabb attitűdöket kapcsolnak a szolgálathoz (vö. Zsolnai-Kasik 2006).

Korábbi kutatási eredményeink szerint (Markos 2015; Bodó 2016) az oktatási intézmény típusa alapvetően befolyásolta a közösségi szolgálattal kapcsolatos tapasztalatokat. Feltételezzük, hogy a szakgimnazista/szakközépiskolás diákok negatívabb attitűdökről adnak számot, mely elsősorban a szakmai gyakorlatuknak és esetlegesen más típusú tanári attitűdnek köszönhető. Ez előbbi nehezíti számukra a közösségi szolgálat szabadidejükben történő végzését - nagyobb terhet róva rájuk mint gimnazista társaikra, 
akiknek nincsen ilyen jellegű kötelezettségük. Utóbbi pedig jelentősen nehezíti a diákok pozitív hozzáállását, mert ebben nem vagy csak elvétve kapnak pedagógiai megerősítést.

Korábbi kutatásaink során vizsgáltuk, hogy a közösségi szolgálat milyen készségeket fejleszt (lásd még Bodó 2018). Az eredmények azt mutatták, hogy hasonlóan az önkéntességhez (Fényes et al. 2015) elsősorban a szociális, az állampolgári, a munkaerőpiaci és az interkulturális készségeket fejleszti a szolgálat. Jelen kutatásunkban hasonló készségcsoportok kialakulását várjuk, és feltételezzük, hogy a háttérváltozók mentén jelentős különbségek mutathatók ki a készségcsoportok kapcsán.

Kutatásunkban a 2016/17-es tanévben 12. és 13. évfolyamos középiskolás diákokat kérdeztünk meg országos szinten $(N=1424)$. Elemszámtartó, súlyozott adatbázisunk nemre és iskolatípusra (gimnázium, szakgimnázium/szakközépiskola) vonatkozóan országosan reprezentatív. A megkérdezés önkéntes alapon történt, így a reprezentativitást ez befolyásolja, ahogy a kitöltés körülményei is torzítást eredményezhettek. Árnyalja a képet, hogy a beérkező adatok alapján elsősorban csoportos, osztályonkénti kitöltésre került sor, ami lehetővé teszi a különböző vélemények megjelenését a diákok legszélsőségesebb megnyilvánulásait is beleértve. Ezekkel a tényezőkkel számolnunk kell a végső következtetések levonásakor. Vizsgálati módszereink: alapstatisztikák, főkomponenselemzés és varianciaelemzés.

\section{Eredmények}

Elsőként azt vizsgáltuk, hogy előzetes elvárásaiknak mennyiben felelt meg és milyen tapasztalatokkal rendelkeznek a diákok a közösségi szolgálattal kapcsolatban (1.ábra). $\mathrm{Az}$ 1. ábrán látható, hogy a diákok megítélésük szerint többnyire hasznos tevékenységet végeztek az 50 óra alatt, és a való élet alkotta helyzetekben próbálhatták ki magukat

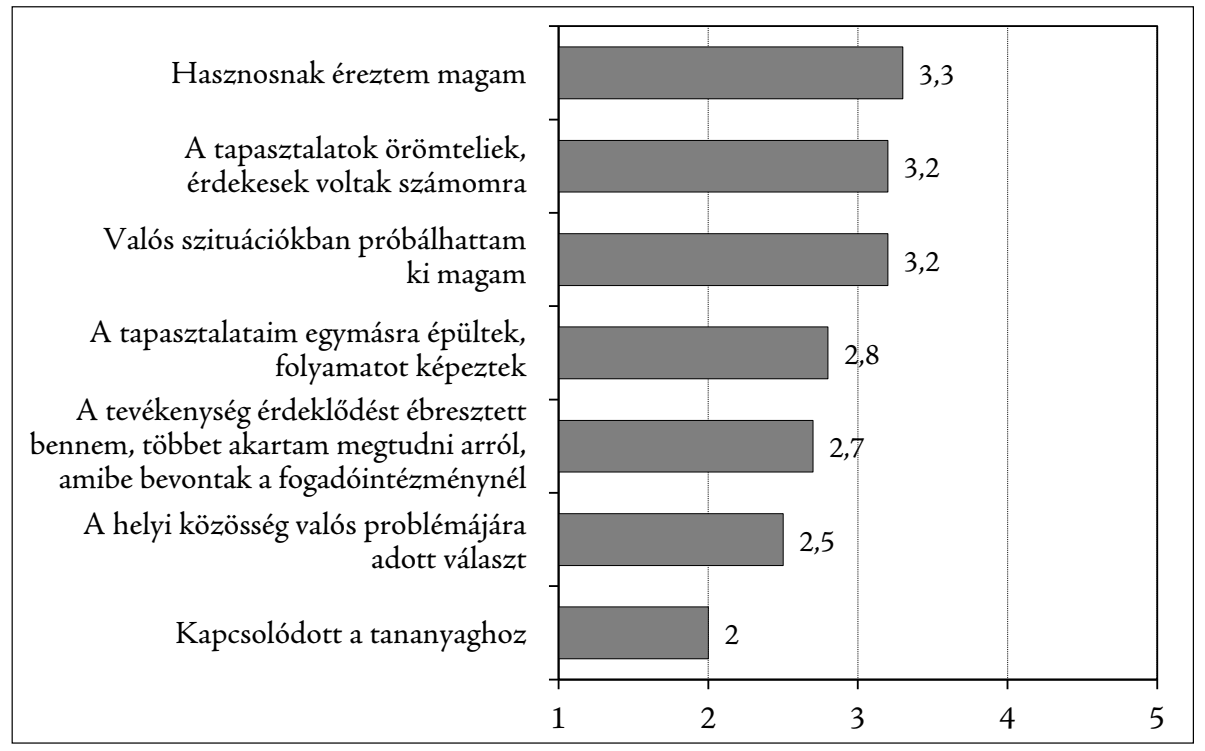

1. ábra: A közösségi szolgálattal kapcsolatos attitűdök 1-5 fokú skálán (1 = egyáltalán nem felelt meg, 5 = maximálisan megfelelt $)(N=1424)$. Forrás: EKE OFI 2017 
(a közösségi szolgálatnak többek között ez az egyik főbb célja). A tevékenységek során szerzett élmények többnyire örömteliek és érdekesek voltak számukra. Ugyanakkor kevésbé érezték úgy, hogy a tapasztalatok egymásra épültek, és egy tanulási folyamat részét képezik. Az adatok azt mutatják, hogy a diákok számára kevésbé volt érdekes a tevékenység, hogy abba mélyebben bevonódjanak, és akár tovább tevékenykedjenek a fogadó szervezetnél. A diákok kevésbé érezték azt, hogy a végzett tevékenység megoldást jelenthet a helyi közösség problémáira. Ebben a tekintetben szemléletváltásra lenne szükség. Jelenleg az iskolák többsége nem az igények alapján szervezi az IKSZ-et, hanem a diákok kötelezettségéhez keres feladatot. Az igények szerinti közösségi szolgálat szervezésében az iskolai vagy települési börzék jelenthetnek hatékony megoldást. Az ábra azt is mutatja, hogy a diákok nem tudták összekapcsolni a szerzett tapasztalatokat a tananyaggal, mely szintén a felkészítő és feldolgozó órák feladata lenne. Ezzel kapcsolatban az elvárások csak mérsékeltek lehetnek, mert a magyar iskolai közösségi szolgálat tanításon kívüli tevékenységnek számít.

A további eredmények azt mutatták, hogy az iskola típusa nem függ össze az attitüdökkel, tehát nem mutatható ki a gimnazista és szakgimnazista/szakközépiskolás, ${ }^{1}$ tanulók tapasztalatai között különbség.

A nem változó azonban befolyásolta a közösségi szolgálathoz való hozzáállást. Az átlagosnál pozitívabb véleménnyel a lányok 56\%-a, míg a fiúk 44\%-a nyilatkozott a

1. táblázat: A készségitemek együttjárása * (faktorsúlyok) $(N=1424)$

\begin{tabular}{lccc}
\hline Készségek & $\begin{array}{c}\text { Állampolgári } \\
\text { készségek }\end{array}$ & $\begin{array}{c}\text { Pályaorientációs } \\
\text { készségek }\end{array}$ & $\begin{array}{c}\text { Elöítélet-mentes } \\
\text { készségek }\end{array}$ \\
\hline Kommunikációs készség & 0,529 & & \\
Kapcsolatépítés & 0,514 & & \\
Együttmúködő készség & 0,483 & & \\
Konfliktuskezelés & 0,556 & & \\
Odafigyelek másokra & 0,556 & & \\
Tolerancia & 0,502 & & \\
Önismeret & 0,459 & & \\
Állampolgári tudatosság & 0,454 & & 0,679 \\
Döntésképesség & 0,543 & & \\
Pályaválasztási döntéshozás & & 0,549 & \\
Tanár-diák kapcsolat & & 0,619 & \\
Elöítélet csökkenése & & &
\end{tabular}

* Főkomponensmódszerrel történő faktoranalízis rotálás nélkül. A három faktor által magyarázott variancia 41,61\%. Adott faktorba azon változók kerültek, melyek kommunalitása nagyobb mint 0,25. A három faktor saját értéke > 1. Forrás: EKE OFI 2017

Megjegyzés: A fókomponensek elóállítási módszere: Principal Component Elemzés

1 Kutatásunkban szakközépiskolás diákokat is megkérdeztünk, hiszen a szakközépiskolák egy részében lehetőség van plusz kétéves, érettségit adó nappali képzésben részt venni, és számukra is kötelező az iskolai közösségi szolgálat. 
közösségi szolgálat kapcsán szerzett tapasztalatokról $(p=0,000)$. Ez az eltérés adódhat a nemek közötti eltérő személyiségvonásokból is, melyet Zsolnai és Kasik (2006) kutatási eredményei is igazoltak.

$\mathrm{A} z$ attitűdök vizsgálatát követően azt vizsgáltuk, hogy az általunk felsorolt kilenc készségitemből milyen csoportok rajzolódnak ki. Főkomponens-elemzés segítségével Fényes és munkatársai (2015) csoportosításához hasonlóan - ahol a szerzők három fö kompetenciacsoportot vizsgáltak: interkulturális, állampolgári és szociális - három készségcsoport alakult ki: állampolgári, pályaorientációs és az elöítélet-mentes készségek csoportjai. Az itemek megoszlása alapján az első csoportot az állampolgári készségek csoportjának neveztük el, hiszen olyan készségek tartoznak közé, melyek elengedhetetlenek a felelős állampolgári léthez. Tartalmaznak egyrészt szociális készségeket (együttműködés, empátia, kommunikációs készség, másokra való odafigyelés stb.) és civil aktivitásra mutató készségeket is (állampolgári tudatosság, döntéshozó képesség stb.). A második készségcsoportot a pályaorientációs készségek alkotják. Ide olyan itemek tartoznak, mint a pályaválasztási döntéshozás képessége és a jó tanár-diák kapcsolat. Ez utóbbi fontos támogató faktorként jelenhet meg a pályaorientáció kapcsán, hiszen a támogató pedagógusi attitüd sokszor tanulói életutakat is befolyásol. A harmadik készségcsoportba egyetlen item került, az előítélet csökkenése (1. táblázat).

Varianciaanalízis segítségével vizsgáljuk a fökomponenseket háttérváltozók (nem, oktatási intézmény típusa, fenntartója) menti bontásban. Szignifikáns az összefüggés a három főkomponens és a nem változó között. A három készségcsoport az állampolgári készségekkel és a pályaorientációs készségekkel mutatott statisztikai összefüggést. Ennek értelmében míg a lányoknak átlag feletti mértékben fejlődtek az állampolgári készségeik, és átlag alatti mértékben a pályaorientációs készségeik, addig a fiúknak a pályaorientációs készségeik fejlődtek átlag feletti mértékben, és az állampolgári készségeik kevésbé (2. táblázat).

Ennek okát a nemek közötti biológiai és szociális érés időszakának különbségei okozhatják, hiszen a lányok érése megelőzi a fiúkét, továbbá magyarázhatja az is, hogy a lányok szociális kompetenciái fejlettebbek, mint a fiúké. A fiúk véleménye szerint elsősorban a pályaorientációs készségeik fejlődését segíti a szolgálat. Valószínűsíthető, hogy a fiúk a lányokkal ellentétben a szolgálat keretén belül nagyobb hangsúlyt fektetnek arra, hogy

2, táblázat: A főkomponensek értékei nemek szerint

\begin{tabular}{llccc}
\hline Nem & Állampolgári & $\begin{array}{c}\text { Pályaorientációs } \\
\text { készségek }\end{array}$ & $\begin{array}{c}\text { Elöítélet-mentes } \\
\text { készségek }\end{array}$ \\
\hline \multirow{2}{*}{ Fiú } & Átlag & $-1,112$ & 0,147 & $-0,017$ \\
\hline \multirow{2}{*}{ Lány } & $N$ & 702 & 702 & 702 \\
\hline \multirow{2}{*}{ Összesen } & Átlag & 0,109 & $-0,143$ & 0,017 \\
& $N$ & 722 & 722 & 722 \\
\hline ANOVA & Átlag & 0,000 & 0,000 & 0,000 \\
\hline
\end{tabular}

Forrás: EKE OFI 2017 
BODÓ MÁRTON - MARKOS VALÉRIA: AZ ISKOLAI KÖZÖSSÉGI SZOLGÁLAT...

3. táblázat: A főkomponensek értékei az oktatási intézmény típusa szerint

\begin{tabular}{llccc}
\hline Iskolatípus & Állampolgári & $\begin{array}{c}\text { Pályaorientációs } \\
\text { készségek }\end{array}$ & $\begin{array}{c}\text { Elöítélet-mentes } \\
\text { készségek }\end{array}$ \\
\hline \multirow{2}{*}{ Gimnázium } & Átlag & 0,065 & $-0,079$ & 0,052 \\
& Elemszám & 515 & 515 & 515 \\
\hline Szakgimnázium, & Átlag & $-0,037$ & 0,044 & $-0,029$ \\
Szakközépiskola & Elemszám & 909 & 909 & 909 \\
\hline \multirow{2}{*}{ Összesen } & Átlag & 0,000 & 0,000 & 0,000 \\
\hline ANOVA & Elemszám & 1424 & 1424 & 1424 \\
\hline
\end{tabular}

Forrás: EKE OFI 2017

összekapcsolják a tanulmányi vagy érdeklődési területükkel a végzett tevékenységet, vagy épp a szolgálat során jönnek rá arra, hogy a program segítheti a pályaorientációjukat.

Tovább vizsgálva a képzett fökomponensek és az oktatási intézmény típusa közötti összefüggéseket látható, hogy az intézmény típusa és a pályaorientációs készségek között is kimutatható jelentős összefüggés. Átlag alatti mértékben a gimnazistáknak fejlődtek a pályaorientációs készségeik, míg a szakgimnazistáknak/szakközépiskolásoknak átlag feletti arányban fejlődött ez a fajta készsége. Az állampolgári és elöítéletmentes készségek kapcsán nem mutatható ki eltérés a különböző oktatási intézmények típusai mentén (3, táblázat).

Korábbi kutatási eredményeink (Markos 2016) rávilágítottak arra, hogy a szakközépiskolában/szakgimnáziumban tanuló diákok arra törekszenek, hogy a közösségi szolgálati tevékenységeiket összekapcsolják a tanult szakmájukkal. Feltehetően ez magyarázza fenti eredményeinket, miszerint a pályaorientációs készségek a szakmát tanulók körében fejlődtek jobban. A közösségi szolgálat lehetőséget nyújt egyrészt arra, hogy a kötelező szakmai gyakorlaton túl a választott szakterületen több munkaórában tevékenykedjenek, mely hozzájárulhat ahhoz, hogy megerősítse őket a pályaválasztásukban. Másrészt a különböző fogadóintézményeknél töltött szolgálat során lehetőségük nyílhat arra is, hogy olyan szakmai kapcsolatokat építsenek ki, mely a munkaerőpiacra lépést követően megtérülhet számukra.

Sigmon (1994) modelljének figyelembevételével úgy véljük, elöször abban kellene döntenie az iskolának, hogy milyen céllal szervezik meg a szolgálatot. A két képzési típus között mutatkozó közösségi szolgálatra vonatkozó eredmények adalékul szolgálhatnak a képzési típusok közti általános különbségek megrajzolásához.

Az oktatási intézmény típusán túl vizsgáltuk az egyes készségcsoportok összefüggéseit iskolafenntartó szerinti bontásban, ahol az állami, az egyházi és az alapítványi iskolák mentén tártuk fel a különbségeket. A kialakult készségcsoportok közül az állampolgári készségek csoportja és az előítélet-mentes készségcsoport mutatott szignifikáns összefüggést az iskolafenntartók típusaival. A 4. táblázat alapján megállapítható, hogy az állampolgári készségek fejlődéséről elsősorban az állami és az egyházi fenntartású intézmények tanulói számoltak be átlag feletti mértékben, míg az alapítványi intézmények tanulói körében átlag alatti arányban fejlődött ez a készségcsoport. Az elöítélet-mentes készségek fejlődése kapcsán pedig az látható, hogy az egyházi fenntartású 
4, táblázat: A fókomponensek értékei iskolafenntartók szerint

\begin{tabular}{llccc}
\hline Iskolafenntartó & Állampolgári & $\begin{array}{c}\text { Pályaorientációs } \\
\text { készségek }\end{array}$ & $\begin{array}{c}\text { Elöítélet-mentes } \\
\text { készségek }\end{array}$ \\
\hline \multirow{2}{*}{ Állami } & Átlag & 0,025 & 0,017 & $-0,015$ \\
& Elemszám & 1077 & 1077 & 1077 \\
\hline \multirow{2}{*}{ Egyházi } & Átlag & 0,011 & $-0,071$ & 0,010 \\
& Elemszám & 235 & 235 & 235 \\
\hline \multirow{2}{*}{ Alapítványi } & Átlag & $-0,322$ & $-0,027$ & $-0,245$ \\
& Elemszám & 75 & 75 & 75 \\
\hline \multirow{2}{*}{ Összesen } & Átlag & 0,004 & 0,000 & $-0,007$ \\
& Elemszám & 1387 & 1387 & 1387 \\
\hline ANOVA & & 0,015 & 0,452 & 0,028 \\
\hline
\end{tabular}

Forrás: EKE OFI 2017

iskolákban nőtt átlag feletti mértékben ez a készségcsoport. Feltehetőleg ennek az az oka, hogy az egyházi fenntartású iskolák, hitbéli meggyőződésükből kifolyólag nagyobb hangsúlyt fektetnek az elöítélet-mentes nevelésre és a szociális, állampolgári készségek fejlesztésére. Azt sejtjük, hogy ez a nevelési elv a fogadóintézményi kínálatnál is megmutatkozhat, és ez okozza azt, hogy az itt tanulók nagyobb készségfejlődésről számoltak be az említett két területen. A táblázat azt is mutatja, hogy az alapítványi fenntartású intézmények esetén minden készségcsoport átlag alatti mértékben fejlődött. Ennek okainak feltárása a jövőbeni fontos kutatási célunk.

\section{Összegzés}

Összességében látható, hogy a közösségi szolgálattal kapcsolatos attitűdök mentén nemi különbségek mutathatók ki. A diákok előzetes elvárásaikhoz képest alapvetően hasznosnak, örömtelinek és élvezetesnek tartják a közösségi szolgálatot, ami jó kiindulópont lehet készségeik fejlesztéséhez.

Hipotézisünk, miszerint a Fényes és munkatársai (2015) által képzett faktorok a közösségi szolgálat kapcsán kirajzolódnak, nem igazolódott be. Bár az állampolgári készségcsoport a mi vizsgálatunkban is megjelent, azonban magába foglalta a szociális készségeket is. Az állampolgári készségek mellett elöítélet-mentes és pályaorientációs főkomponenseket különböztettünk meg. Míg a lányoknál átlag felett fejlődtek az állampolgári készségeik, addig a fiúknak a pályaorientációs készségeik fejlődtek nagyobb arányban, melyet biológiai és szociális okokkal magyarázatunk. A pályaorientációs készségek fejlődése az oktatási intézmény típusával mutatott összefüggést, azaz elsősorban a szakgimnazista/szakközépiskolás diákok esetében mutatható ki készségfejlődés. Ennek okát a szakirány és a közösségi szolgálati tevékenység könnyebb összeegyeztethetőségében látjuk. További eredményünk, hogy az egyházi fenntartójú intézmények tanulói körében nagyobb arányban nőttek az állampolgári és elöítélet-mentes készségek, mint az egyéb fenntartójú intézményekben, mely az egyházi intézmények nevelési elveivel hozható összefüggésbe. 
A kutatási eredmények reményeink szerint abban tudnak segítséget nyújtani a program helyi kialakítóinak, hogy milyen irányba fejlesszék az általuk kialakított programokat annak érdekében, hogy az általuk kitüzött nevelési célokat elérhessék.

\section{IRODALOM}

Bodó M. (2016) A pedagógusszerep és az Iskolai Közösségi Szolgálat. Kapocs folyóirat, Vol. 15. No. 69. pp. 3-14.

Bodó M. (2018) Iskolai Közösségi Szolgálat - fenntarthatóság és minőség dilemmája a köznevelésben. In: Ollé J. \& MiKa J. (eds) Iskolakultúra és környezetpedagógia. Budapest, ELTE Eötvös Kiadó, pp. 29-40.

Bodó M., Markos V., Mézes J., Sárosi T. \& Szalóki M. (2017) Az iskolai közösségi szolgálat a 9. és 12. évfolyamos diákok véleménye tükrében. Új Pedagógiai Szemle, Vol. 67. No. 9-10. pp. 41-71.

Fényes H., Kovács K., Dusa Á. R., Fekete A., Kardos K., Kovács E., Márkus Zs., Morvai L., Nagy Z., Sebestyén K. \& Varga E. (2015) Felsőoktatásban részt vevő hallgatók különböző kompetenciáinak mérési lehetőségei. In: PusztaI G. \& Kovács K. (eds) Ki eredményes a felsőoktatásban? Nagyvárad-Budapest, Partium KönyvkiadóPersonal Problems Solution-Új Mandátum Könyvkiadó.

Karlowits-Juhász O. (2015) A jezsuiták szeretetszolgálata a kötelezö iskolai közösségi szolgálat kontextusában. https://drive.google.com/file/d/1wnfzMw00sJPvsnep7vibjGS6N4yUlcc/view [Letöltve: 2018. 07. 22.]

Markos V. (2015) Az iskolai közösségi szolgálat iránti attitüdök a középiskolások körében. In: Dов E. (ed.) Juvenilia VI. Debreceni bölcsész diákkörösök antológiája. Debrecen, Printart-Press Kft. pp. 209-224.

Markos V. (2016) A nyíregyházi középiskolás diákok iskolai közösségi szolgálattal kapcsolatos tapasztalatainak vizsgálata. Párbeszéd: Szociális Munka Folyóirat, Vol. 3. No. 4. p. 14.

Markus, G. B., Howard, J. P. \& King, D. C. (1993) Integrating Community Service and Classroom Instruction Enhances Learning: Results from an Experiment. Educational Evaluation and Policy Analysis, Vol. 15. pp. 410-419.

Matolcsi Zs. (2013) Iskolai közösségi szolgálat, mint pedagógiai eszköz. Neveléstudomány: oktatás - képzés - innováció, Vol. 1. No. 4. pp. 70-83.

Sigmon, R. L. (1994) Serving to Learn, Learning to Serve. Linking Service with Learning. Washington DC, Council for Independent Colleges Report.

Velkey B. (2014) A középiskolai közösségi szolgálat tapasztalatai. Szakdolgozat, BME GTK APP.

Zsolnai A. (1998) A szociális kompetencia fejlettsége serdülőkorban. Magyar Pedagógia, Vol. 98. No. 3. pp. 187-210.

Zsolnai A. \& Kasık L. (2006) A szociális kompetencia fejlödése 12, 15 és 16 éves tanulók körében. VI. Országos Neveléstudományi Konferencia, Budapest, 2006. október 26-28. Konferenciakötet 123.

A cikk a Creative Commons Attribution 4.0 International License (https://creativecommons.org/licenses/ by/4.0/) feltételei szerint publikált Open Access közlemény, melynek szellemében a cikk bármilyen médiumban szabadon felhasználható, megosztható és újraközölhető, feltéve, hogy az eredeti szerző és a közlés helye, illetve a CC License linkje és az esetlegesen végrehajtott módosítások feltüntetésre kerülnek. (SID_1) 